\title{
Impact of Varying Light Duration on Radial Growth of Pink Oyster Mushroom
}

\section{Praneet Chauhan* and Dharmesh Gupta}

Department of Plant Pathology, Dr. Y. S. Parmar University of Horticulture and Forestry, Nauni, Solan-173 230 (HP), India

*Corresponding author

\section{A B S T R A C T}

Keywords

Light duration,

Pleurotus djamor,

Radial growth.

Article Info

Accepted:

07 September 2017

Available Online:

10 November 2017
Light is an important factor deciding about yielding and morphological characters of Pleurotus carpophores. The objective of the research was to ascertain the impact of different light periods on radial growth of Pleurotus djamor, the pink oyster. The culture of P.djamor in petri plates were exposed to varying light period viz.6h light $18 \mathrm{~h}$ darkness, $9 \mathrm{~h}$ light $15 \mathrm{~h}$ darkness, $12 \mathrm{~h}$ light $12 \mathrm{~h}$ darkness, $18 \mathrm{~h}$ light $6 \mathrm{~h}$ darkness, $15 \mathrm{~h}$ light $9 \mathrm{~h}$ darkness, $24 \mathrm{~h}$ light $0 \mathrm{~h}$ darkness, respectively. Maximum growth of $75.33 \mathrm{~mm}$ was recorded in $6 \mathrm{~h}$ light and $18 \mathrm{~h}$ darkness and it was significantly higher than the $18 \mathrm{~h}$ light and $9 \mathrm{~h}$ exposure to the light.

\section{Introduction}

Mushrooms have been cultivated since ancient times for their nutritional value and flavor especially in the far eastern countries. The protein found in mushroom is far less than in animals but much more than in most plants. They have low fat content, high fibre and all essential amino acids and with the exception of iron, contain all important minerals too (Sadler, 2003).

Pleurotus spp. are commonly known as oyster mushroom because of their tongue shaped pileus with an eccentric lateral stipe. Many species of Pleurotus have worldwide distribution in nature which grows saprophytically on dead wood logs and trunk of trees. They have a wide range of ecological adoption and also have the ability to transform natural wastes into edible biomass. Yields of mushrooms from the Pleurotus genus depend on many factors; apart from genetic properties, environmental factors also play a significant role in this regard (Lalley, 1991; Shah et al., 2004). The mycelium of the mushrooms from the Pleurotus genus does not require light for its growth (Sharma, 2004). Nevertheless, light is necessary for the proper development of carpophores (Royse and Zaki, 1991). Trukhonovets (1991) maintains that during the period of carpophores development and growth, light is an important factor deciding about the yielding and morphological characters of fruiting bodies. 


\section{Materials and Methods}

The experiment was conducted at the Mushroom Research Laboratory, Department of Plant Pathology, Dr. Y.S. Parmar university of Horticulture and Forestry during 2012-13. The culture of Pleurotus djamor was obtained from Directorate of Mushroom Research, Chambaghat, Solan and maintained on potato dextrose agar (PDA) slants. The plates containing $20 \mathrm{ml}$ of PDA medium were inoculated with $3 \mathrm{~mm}$ discs of $P$. djamor obtained from 7 days actively growing culture. The plates were incubated at $25 \pm 1^{\circ} \mathrm{C}$ in growth chamber and were provided with light for different duration.

\section{Results and Discussion}

Light, along with other external factors, exerts a significant impact on the growth and development processes of carpophores of mushrooms from the Pleurotus genus.

It acts as a signal triggering off various biophysical and biochemical processes ultimately leading to morphological and phototrophic reactions (Trukhonovets, 1991).

To find out the optimum light period for mycelial growth of $P$. djamor, the fungus was exposed to varying light periods of $6 \mathrm{~h}, 9 \mathrm{~h}$, $12 \mathrm{~h}, 15 \mathrm{~h}, 18 \mathrm{~h}$ and $24 \mathrm{~h}$.

The data presented in Table 1 shows that maximum growth of $75.33 \mathrm{~mm}$ was recorded in $6 \mathrm{~h}$ light and $18 \mathrm{~h}$ darkness and it was significantly higher than the $18 \mathrm{~h}$ light and $6 \mathrm{~h}$ exposure to the light. The lowest radial growth of $30.5 \mathrm{~mm}$ was recorded, when the light and darkness duration was same (Figure $1)$.

Table.1 Effect of different light periods on radial growth of Pleurotus djamor

\begin{tabular}{|l|l|}
\hline Treatments & Radial growth $(\mathbf{m m}) *$ \\
\hline 6h light 18h darkness & 75.33 \\
\hline 9h light 15h darkness & 42.83 \\
\hline 15h light 9h darkness & 34.00 \\
\hline 18h light 6h darkness & 66.30 \\
\hline 24h light 0h darkness & 35.00 \\
\hline 12h darkness 12h light & 30.50 \\
\hline Mean & 47.32 \\
\hline C.D & 18.967 \\
\hline S.E & 8.70 \\
\hline
\end{tabular}




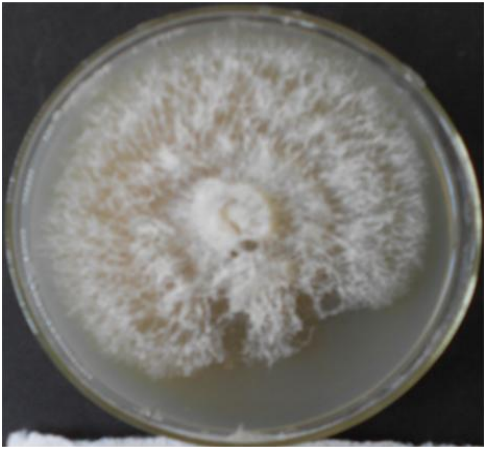

$6 \mathrm{~h}$ light \& $18 \mathrm{~h}$ darkness

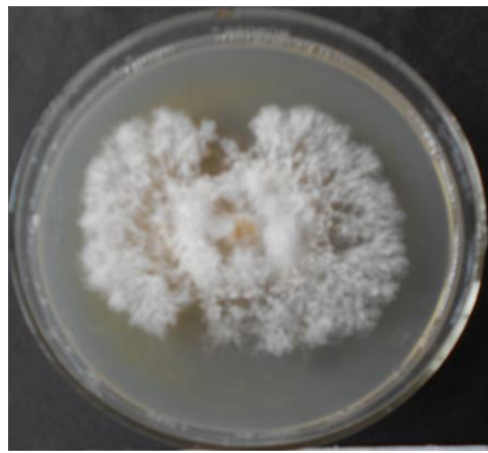

$18 \mathrm{~h}$ light $\& 16 \mathrm{~h}$ darkness

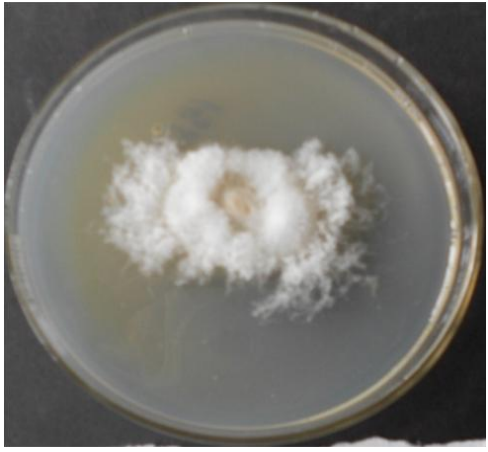

$15 \mathrm{~h}$ light $\& 9 \mathrm{~h}$ darkness

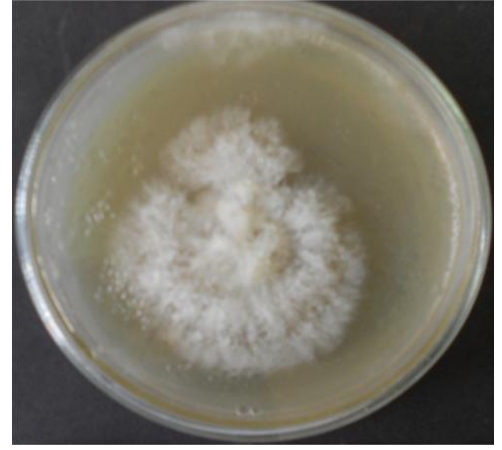

9h light \& $15 \mathrm{~h}$ darkness

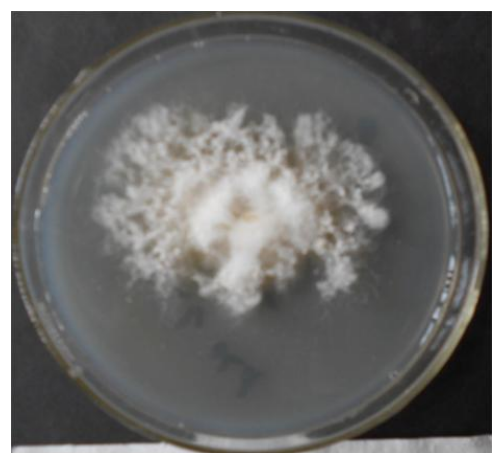

24 h light \& Oh darkness

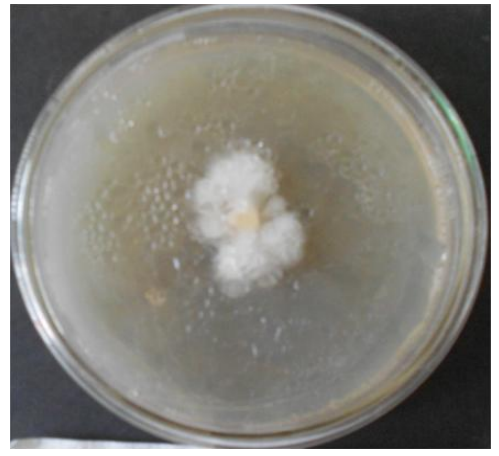

$12 \mathrm{~h}$ light $\& 12 \mathrm{~h}$ darkness

Figure 1. Effect of light on radial growth of Pleurotus djamor

Similar results have been reported by Suharban and Nair (1994) for Pleurotus spp. and Sharma (2004) for P. djamor. Sagar et al., (1994) also reported that the mycelial growth of Suillus sibiricus was inhibited in the presence of light. Although light is not essential for the vegetative growth, however, various workers have reported it to be essential for the formation and maturation of reproductive structures of wood rotting fungi (Eger, 1978).

\section{References}

Eger G 1978. Biology and breeding of Pleurotus In: The biology and cultivation of edible mushrooms (eds.) S T Chang and W A Hayes, Academic Press. New York. Pp 497-519.

Lelley J 1991. Pilzanbau. Biotechnologie der Kulturspeisepilze. Ulmer, Stuttgart, 404 pp. 
Royse D I and Zaki S A 1991. Yield stimulation of Pleurotus sp. by dual nutrient supplementation of pasteurized wheat straw. In: Science and cultivation of edible fungi (ed.) M.J. Maher. Balkema, Rotterdam. Pp 545-547.

Sadler M 2003. Nutritional properties of edible fungi. British Nutrition Foundation Bulletin. 28: 305-308.

Sagar A, Lakhanpal T N and Singh L 1994. Proceedings of National Symposium "Mushrooms" April 8-10. 27pp.

Shah Z A, Ashraf M, and Ishtiag M 2004. Comparative study on cultivation and yield performance of oyster mushroom
(Pleurotus ostreatus) on different substrates. Pakistan Journal of Nutrition 3(3): 158-160.

Sharma B B 2004. Effect of duration of light on radial growth of pink oyster mushroom. Indian Phytopathology 57(2): 234.

Suharban M and Nair M C 1994. Physiological studies on Pleurotus. Mushroom Research 3(1): 99.

Trukhonovets V V 1991. Effect of illumination intensity on the formation of fruiting bodies in Pleurotus ostreatus (Jacq. Fr.) Kumm. Ukrainian Journal of Botany 48(2): 67-72.

\section{How to cite this article:}

Praneet Chauhan and Dharmesh Gupta. 2017. Impact of Varying Light Duration on Radial Growth of Pink Oyster Mushroom. Int.J.Curr.Microbiol.App.Sci. 6(11): 368-371. doi: https://doi.org/10.20546/ijcmas.2017.611.041 